\title{
THE REGIONAL TRANSMISSION OF UK MONETARY POLICY
}

\section{Sheila C Dow and Alberto Montagnoli`}

\begin{abstract}
Concerns have been raised in the media about a 'one-size-fits-all' monetary policy for the UK. If there are diverse economic conditions in different regions, then a unitary monetary policy cannot suit all. The purpose of this paper is to explore this issue further by breaking it down into two separate issues. First there is the more conventional way of considering the question, in terms of the effect of a particular interest rate change on regions experiencing different economic conditions. This requires a consideration of the nature and causes of regional economic disparities in the UK, and how these might be affected by particular interest rate changes. But there is further the question of how monetary policy is transmitted to the different regions. The possibility is considered that there may be regional differences in how a particular monetary policy is translated into different financial conditions in different regions. In other words there may be a regional dimension to the transmission process itself. The focus here will be on the regional structure of the financial sector and financial behaviour, and in particular the credit market. The argument is explored further with a comparison of Scottish and UK data.
\end{abstract}

JEL classifications: E50, R11, R51

Keywords: Scotland, UK, monetary policy, regional economies

\footnotetext{
- Department of Economics, University of Stirling, Stirling FK9 4LA Tel: 01786-467474 and -467478

e-mail: $\underline{\text { s.c.dow@stir.ac.uk and alberto.montagnoli@stir.ac.uk }}$
} 


\section{Introduction ${ }^{1}$}

The formation of European Monetary Union (EMU) has drawn attention to the issue of the potentially differential impact of monetary policy on different economies within a monetary policy area. This was natural, since EMU involved member governments giving up any scope for an independent national monetary policy. In the UK in particular, as debate continues as to the costs and benefits of joining EMU, the key issue is how monetary policy designed by the European Central Bank (ECB) will affect the UK economy, relative to a continuation of the status quo.

But the issue has been extant in the regional literature for a long time (see RODRIGUEZ FUENTES and DOW, 2003, for a review). Academic research in this area has been most active where regionalism has been a political issue, notably in the US, and where there are relatively good regional data (see for example MILLER, 1977). The regional impact of monetary policy has been a political issue up to a point elsewhere, as in the UK, and the subject has attracted some attention here (EVANS and McCORMICK, 1994, and BLAKE, 1995). But research has been hampered by a relative absence of regional economic and financial data (see further BELL, 1993). There are some signs of improvement in this respect. The two reviews conducted by Christopher Allsopp for the Treasury, the Bank of England and the Office of National Statistics (ONS) (ALLSOPP, 2003 and 2004) have set an agenda for improved regional data. Further the Bank of England's Monetary Policy Committee (MPC) receives reports on regional economic conditions from its Regional Agents, as input to monetary policy-making. But this input is reported in consolidated form, rather than as a mechanism for focusing on regional difference. 
The traditional, reduced-form regional analysis focusses on the transmission of monetary policy through aggregate demand to prices via the labour market (using Phillips curve analysis). This type of analysis is still evident in Bank of England analysis (as set out for example in the Inflation Report). Indeed one argument for paying attention to the regional dimension is that, if the inflation/unemployment trade-off is different in different regions, then the national trade-off which aggregates the regional trade-offs is less favourable (ARCHIBALD, 1969); monetary policy would be more efficient with a more homogeneous Phillips curve trade-off. Warning signals for rising inflation are likely to emerge from the regions which are bumping up against full capacity. Even if all regions are ranged along a common Phillips curve, then the more prosperous regions would be in the less elastic portion, so that the target reduction in UK-wide wage inflation would require a smaller increase in unemployment than the rest of the economy. Without knowing more about the transmission of monetary policy through labour markets, however, it is impossible to arrive at any conclusion as to whether different regional Phillips curves relationships would mean the monetary policy would tend to increase or reduce regional disparities.

The expectation has tended to be that monetary policy would serve to increase regional disparities. This expectation was reinforced by structural analysis, focusing on the different interest rate elasticities for different industries (FISHKIND 1977). Peripheral regions tend to be more dependent on fewer industries, the primary and manufacturing sectors more than services, and with export orientation, so that the exchange rate effects of monetary policy would have greater impact there (see for example BLAKE 1995, GANLEY AND SALMON, 1997). 
But the evidence set out in recent studies, within the constraints posed by data limitations, suggests that, overall, the effect of monetary policy, instead, is in the direction of reducing regional disparities. BLAKE (1995) provides an analysis within a more general analysis of the regional impact of macroeconomic policy in the UK. A range of factors was considered to explain the estimated differences in the interest elasticity of regional demand, which showed the South East region to have the higher elasticity. Similarly, EVANS and McCORMICK (1994) considered the regional impact of monetary policy as one factor explaining the reduction in regional disparities in the UK during 1990-93. Both papers focused on regional patterns in mortgage borrowing as a key financial factor leading to a differential regional impact of monetary policy in the UK. EVANS and McCORMICK (1994) also considered credit rationing to explain why a higher interest burden on some regions with high borrowing would be an effective constraint on demand. But there was no suggestion of a regional dimension to credit rationing itself.

These different views on the regional impact of monetary policy may reflect changes in the actual transmission of monetary policy over time, and/or changes in the way in which it is analysed. In this paper we extend the analysis of the regional impact of monetary policy in the UK by drawing on the more recent monetary policy literature ${ }^{2}$. We focus on regional differences in financial structure, as well as industrial structure. We attempt to break down the means by which monetary policy is transmitted, to consider how these means might differ by region and how this might be identified empirically. In other words we consider the possibility of regional differences in the effect of a given monetary policy on the cost and availability of credit. A range of different types of evidence for the UK is then considered in relation to the analysis. 


\section{The Regional Transmission of Monetary Policy}

In its simplest form, monetary policy is represented by a change in the repo rate ${ }^{3}$, and its economic impact is measured in terms of the associated change in the price level and output. Monetary policy is designed to keep UK inflation within a one-percentage point band around the $2 \%$ target inflation rate in terms of CPI. ${ }^{4}$ The decision on the repo rate is taken monthly by the Monetary Policy Committee (MPC). The primary evidence base is their quarterly Inflation Report, which presents forecasts for CPI and GDP over the two-year policy horizon (now supplemented by a further one year forecast period to indicate trends). If the forecast is for inflation to exceed the target rate by the end of the period, the decision, other things being equal, is to raise the repo rate, and vice versa for an inflation rate which is forecast to fall below the target. Other considerations would be whether this outcome for inflation is expected to be reversed quickly in any case (as in RPIX, where house price inflation, as the proxy for house maintenance, was felt to be distorting the picture), or whether there is particular uncertainty surrounding the forecast.

Both the theory of monetary policy itself and the regional impact of monetary policy literature have moved in the direction of unpacking the various aspects of the transmission of monetary policy, in order to understand the aggregate outcomes better. Indeed, given the focus of the regional literature on differential regional impact, understanding the sources of regional difference has been crucial. If we are to continue to assume that monetary policy is transmitted in a homogeneous manner to all regions, then this requires justification. We can draw on recent developments in 
the monetary policy literature, therefore, to consider more carefully the mechanisms by which monetary policy is transmitted ${ }^{5}$.

The nature of the transmission mechanism is by no means settled in the monetary policy literature, not least because much of the effect may follow from pronouncements by the MPC about their analysis and expectations, with credibility being a significant factor (FRIEDMAN, 1999). In other words, on its own, a change in the official interest rate may be a limited indicator of monetary policy. The Bank of England (1999) has set out a range of channels of transmission, by which a change in interest rates affects aggregate demand; see also DE BONDT (2000). These range from market interest rates, to asset prices, to expectations and confidence, to the exchange rate. Much of the recent literature has focused on the lending channel, which refers to the effect of monetary policy on the loan supply curve (see RODRIGUEZ FUENTES, 2005 and WALSH, 2003). We consider this first as a source of regional difference, and then consider a further set of channels which take account of the Bank’s fuller framework.

The bank lending channel: rising interest rates increase the cost of credit which may have differential regional outcomes; the regional dimension is a consequence primarily of the regional composition of the financial sector. This structure refers both to institutional structure (how far there are region-specific institutions) and to the behaviour of national institutions with respect to regional markets. The supply of credit curve may differ regionally and therefore monetary policy would affect the cost and availability of credit more in some regions than others if any of the following factors hold: 
1. Local banks in some regions are more interest sensitive than others in terms of credit supply, because of balance sheet differences. Overall we would expect banks with less liquid balance sheets to respond more fully to monetary policy; see KASHYAP and STEIN (2000). Such differences are becoming of limited relevance in the UK given the increasingly national character of the financial sector. Other economies, such as Germany and Spain, still have regionally-distinct financial sectors.

2. But there can still be a regional pattern to bank credit even with national banks. Their credit creation responds differently in different regions to changes in monetary conditions because of the different regional effects of monetary policy on perceived lender's risk. This will depend not only on the state of local industry, but also on asset values for collateral and on the banks' knowledge capacity. Asset values might be hit harder by a rise in interest rates in peripheral regions, encouraging capital outflow which reinforces this weakening of values. Further, different depths of knowledge with respect to remoter regions on the part of national and local banks, where the latter are present, can be a key factor for credit creation there.

3. The repo rate change may feed through differently into the cost of credit in different regions, where this cost includes fees, charges and product discounts which can more readily vary regionally than posted interest rates. There is some evidence of regional differences in cost of credit in the UK, taking account not only of loan rates but also of service charges (McKILLOP and 
HUTCHISON, 1990). This implies that it is misleading to think in terms of a homogeneous loan rate change following from a repo rate change brought about by the monetary authorities.

4. Differential pricing and availability of credit is facilitated if borrowers in some regions are relatively more dependent on local credit supply (this would be the case if there is a relatively high incidence of small and medium enterprises, SMEs, compared to multinational corporations, MNCs). Even where there is a national banking system, SMEs will be more dependent on banks than larger companies which have access to capital markets (see GANLEY AND SALMON, 1997, for supporting evidence for the UK). There is scope then for the banks to exercise discriminatory monopoly power.

What we would expect to find, therefore, is that inability to raise external finance due to supply constraints would be more of a problem for peripheral regions, and that rising interest rates would have a more powerful effect, being augmented by increases in other fees and charges. The credit supply curve expressed in terms of a common short-term interest rate would be expected to have the normal upward slope for central regions, so that banks are more willing to lend the higher the loan rate, other things being equal. But higher market rates might have a greater impact on total loan costs in peripheral regions and increase banks' concern about default risk (for reasons wellexplained in the New Keynesian literature), so that the credit supply curve might even be negatively sloped (in terms of national short-term interest rates). 
The borrowing channel: there may also be regional variability in the interest elasticity of credit demand, so that the effect of monetary policy on the regional supply curve would have different effects on regional demand.

1. Regional interest-elasticity of demand can differ if the sectoral balance differs by region; this argument could also be extended to the exchange rate channel (where other things being equal the exchange rate appreciates when interest rates rise). On balance, sectors with significant capital requirements and stockholding are more interest-sensitive than others since borrowing costs are a higher proportion of total costs, and export sectors are more exchange rate sensitive. So regions with an emphasis on manufacturing and natural resource extraction, particularly for export, will respond more than others to a rise in borrowing costs. This argument is typical of much of the traditional regional finance literature, and was the conventional explanation for aggregative results showing different effects of national monetary policy on regional GDP, as discussed in the previous section (RODRIGUEZ FUENTES and DOW, 2003).

2. But in addition, some regions may be more interest-sensitive than others in terms of credit demand for reasons of liquidity preference. Past experience of financial vulnerability tends to encourage conservative financial behaviour. If indeed the banks are less willing to lend (eg to refinance loans) and asset prices are expected to weaken, borrowers in peripheral regions will anticipate heightened financial vulnerability. When monetary conditions tighten, therefore, there will be a greater unwillingness to be exposed to debt obligations. Thus the asset price channel may operate through reducing the 
willingness to borrow. Moreover households' wealth portfolio may differ in composition from region to region as a result of both different population structure and financial literacy. In both cases a monetary policy shock is transmitted to the regions in an asymmetric way, preventing the policy to work fully

3. Countering these factors which indicate a flatter demand curve for credit in less prosperous regions is a major factor which reduces demand elasticity: relative lack of access to alternatives to bank finance. This is generally the case for SMEs, but also for borrowers relatively remote from the financial centre. If this effect dominates, then bank borrowing will be discouraged less by interest rate rises; the consequences will then be felt on income and employment.

Expectations/Confidence: both credit demand and supply are influenced by expectations with respect to the regional economy and the confidence held in those expectations.

1. Arguably, monetary policy operates as much by the effect of statements by the MPC members about the reasons for policy decisions and more generally in speeches and publications as it does by changing the repo rate. FRIEDMAN (1999) emphasises the role of central bank announcements in monetary policy, although he also emphasises that these announcements need to have credibility in terms of actual effects of policy on interest rates (see also DOW and SAVILLE, 1990). 
2. There may be differential regional effects if expectations and confidence are more vulnerable to discouragement in some regions than others. If confidence in expectations is punctured, or indeed if expectations are confidently held about worsening demand conditions and about local asset values, then that will discourage both credit demand and supply, and the investment, output and employment which would otherwise have been financed.

3. Further, banks' knowledge base, for risk assessment, is better in some regions (normally in the core) than in others (normally in the periphery) (PORTEOUS, 1995). Then the response of national banks to a change in expectations will tend to be more exaggerated for peripheral regions (see RODRIGUEZ FUENTES, 2005, for evidence along these lines for Spanish regions).

\section{Diagrammatic Treatment of Regional Impact of Monetary Policy}

We turn now to an attempt to illustrate diagrammatically, in simplified form, some of these different mechanisms by which monetary policy may be transmitted differently to different regions through the market for credit. We consider the implications of a rise in the central bank rate, taking account, in turn, of: differential regional access to alternative sources of finance; differential regional risk assessment by banks; and differential effects on borrowers' expectations. Although in practise these factors would operate simultaneously, we show them separately in the interests of clarity. 
For simplicity, we consider a national economy made up of two regional economies, $\mathrm{A}$ and $\mathrm{B}$, where $\mathrm{A}$ is the core region and $\mathrm{B}$ the periphery. The national banking system is treated as having a local monopoly in finance in Region B, while borrowers in Region A have access to alternative sources of finance. ${ }^{6}$ Each region has its own demand for credit curve. Since Region A is the core region, with access to credit from banks elsewhere, it has a more elastic credit demand than region $\mathrm{B}$, which is dependent on the domestic banks. We represent credit demand as AR curves as far as the banking system is concerned, as shown in Figure 1 below, expressed in terms of credit levels, $\mathrm{C}$, and interest rates, i. We analyse the banking system as a discriminating monopoly, being able to separate the two credit markets in the two regions. So the market demand curve is an aggregate of the two regional curves, as is the banks’ national MR curve.

As far as the banking system is concerned, actual expected revenue requires discounting for expected risk. We leave this to one side for the moment, but, for completeness, there should be two sets of AR curves, the steeper ones being the ones faced by the banks. The banks' assessment of loan applications for risk is based on more sound knowledge in region A than in region B (PORTEOUS, 1995), and is therefore less likely to be volatile for A than for B. This analysis departs therefore from the New Keynesian view that objective measures of default risk are in principle available; here we see risk assessment as an exercise conducted under uncertainty, and therefore requiring the exercise of judgement. We will return to this aspect when we consider the effect of monetary policy on risk assessment below (Figure 2). 
The supply of credit is determined by the marginal cost of funds to the bank, which in turn is determined by the rate which the central bank enforces in the money market. This benchmark rate is supplemented by a mark-up reflecting the banks’ own liquidity preference as well as the premium for perceived risk. When the banks lack confidence in their risk assessment, there will be a tendency to divert resources to market investments and away from bank loans; this will be reflected in a higher mark-up. The banks’ MC curve is therefore horizontal up to the point where the mark-up increases, reflecting a reluctance to expand credit indefinitely. This reflects a structuralist endogeneity theory (DOW, 2006). We analyse the transmission of monetary policy through different channels below, separating out the effects of each channel.

Suppose the economy has been overheating (primarily in region A) and the central bank raises the repo rate, explaining that the intention is to dampen economic activity. This shifts up the banks' aggregate MC curve to MC', raising MC in both regions equally. ${ }^{7}$ We consider the effect of a change in the intersection of MC and MR in reach region, by examining the consequences of the change in quantity of credit as the banks move up the regional demand curves. The direct effect, as shown in Figure 1, is for credit to contract in both regions, and by more in region A where demand is more elastic. The cost of credit rises more in region $A$ (from $i_{A}$ to $i_{A}$ ') than in region $B$ (from $\mathrm{i}_{\mathrm{B}}$ to $\mathrm{i}_{\mathrm{B}}$ '), in absolute terms, but proportionately more in region $\mathrm{B}$ relative to the fall in credit level. The effect would appear to be greater for region A, but this is moderated by borrowers having access to alternative sources of finance.

But at the same time, there will also be expectational effects on both lenders and borrowers, adding further channels of transmission. Suppose in the light of the 
prospect of weakening activity, lenders revise their risk assessment more severely for region $\mathrm{B}$, then the demand curve will be discounted more heavily in $\mathrm{B}$ than in $\mathrm{A}$. For simplicity we show this in Figure 2 as a relative steepening of the AR curve for Region $\mathrm{B}$, to $\mathrm{AR}_{\mathrm{B}}$ ', reflecting a lower return to the banks, net of expected defaults, than previously. This causes a shift in $\mathrm{AR}_{\mathrm{UK}}$, and thus $\mathrm{MR}_{\mathrm{UK}}$ cuts $\mathrm{MC}$ at a lower point. The effect this time is a much larger drop in credit in B and a larger increase in borrowing costs, compared to region A. This will have a more marked economic impact, since borrowers in region B do not have access to alternative sources of finance.

Suppose the central bank's analysis of economic conditions conveys the expectation that demand will be reduced as a result of monetary policy, and producers in Region $\mathrm{B}$ are accustomed to being hit relatively hard by a rise in the official rate (because of a dependence on manufacturing for example) or by an appreciation in the exchange rate (because of dependence on exports). We have already analysed monetary policy as a movement along the demand curve in Figure 1, and a rotation of the revenue curves as a result of lenders' expectations in Figure 2. But supposing the demand curve for Region B also shifts as a result of the expectational effects of monetary policy on borrowers; Region B borrowers revise downward the expected return on investment, and revise upwards their perception of risk. Then, as shown separately in Figure 3, we have an additional contraction in Region B credit, but this mechanism tends to reduce borrowing costs.

If we consider reversing this process for a fall in the official rate and a rise in expectations with respect to risk in B (on which the banks are relatively less well- 
informed) and a rise in credit demand in $\mathrm{B}$, and put this together with the analysis above, we would expect, overall, greater volatility in credit totals in B than in A, with consequently greater volatility of output and employment. We are not arguing that monetary policy accounts for all of this volatility. Much of it follows from the kind of economic structure which makes B a peripheral economy. Rather we are arguing that the regional impact of monetary policy may well contribute to that inherent instability.

\section{Further Evidence for the UK Regions}

There is a range of evidence which can be brought to bear in an examination of how far problems associated with a regional transmission of monetary policy might apply to the UK. There is well-established evidence of differences in per capita GDP levels, which, as the Treasury report (HMT, 2001) on regional productivity shows, are large compared to other developed countries. One way of considering regional economic differences, and the impact of monetary policy on these, is in terms of the unemployment-inflation trade-off. These Phillips curve differences in turn would reflect differences in regional economic structure, and/or differences in labour market conditions. We do have regional wage and unemployment data, which allow us to attempt to construct a form of regional Phillips curve for Scotland, in comparison with the South-East, Wales, England and Great Britain as a whole, as shown in Figure 4, for annual averages, 1994-2001. This suggests that monetary policy is less efficient than if the relationships were more homogeneous throughout the UK.

A full interpretation of this data is inhibited by the inability to take account of expectations, and it is generally difficult to identify shifts in short-run relationships, 
due to data limitations. However unemployment and the wage rate in the South-East exhibit a much stronger negative correlation (-0.67) than Scotland (-0.27) and Wales (-0.11). The former shows a higher wage inflation elasticity with respect to unemployment, suggesting that any given change in wage inflation requires a greater adjustment in the labour market of the peripheral regions. Consequently monetary policy is less efficient than if the labour market were more homogeneous.

Without regional price and credit data, we are not in a position to say how far regional prices are reflected in the UK CPI index, or indeed estimate the impact of national monetary policy on regional inflation, or estimate how monetary policy influences the credit markets in the core and in the periphery. National monetary policy may well be associated with different effects on regional prices as well as regional unemployment. Only now are attempts being made to gather regional price data on a UK-wide basis. This reinforces the view that we need to look below the aggregate level in order to understand the reduced form results. We turn now to consider the structural factors which might explain why monetary policy appears to have less impact on Scotland than the UK average.

Let us consider the structural differences between Scotland and the rest of Britain which explain income and employment differentials and which therefore form the background to any analysis of the impact of monetary policy. Regional income differentials, according to the HMT Report (2001), are due to a variety of factors, of which they identify productivity differentials as the most important, but with demand also playing a part. In any case, monetary policy can impact on costs as well as demand, so it is a prior expectation that monetary policy may well impact on regional 
differentials. Empirical evidence from other countries indicates that this is the case elsewhere (see RODRIGUEZ FUENTES, 2005, on the Spanish experience).

BLAKE's (1995, p.154) findings for the interest elasticity of consumption of nondurables during 1988-90, and EVANS and McCORMICK's (1994) finding for the early 1990s which they put down to higher indebtedness in the South-East region lead to the conclusion that monetary policy has greatest impact on the South-East. This counters the expectation, based on our Phillips curve analysis, that the inflationunemployment trade-off is steeper in London and the South-East. One possible explanation is that monetary policy has an even more markedly differential regional effect on wages; unemployment is less affected in Scotland, and therefore (going by the Phillips curves) wages even less so.

Blake and Evans and McCormick draw attention to the housing market as a major structural factor explaining the higher impact of monetary policy on the South-East of England. Higher property values in the South-East are associated with higher levels of borrowing, and thus greater vulnerability to rising interest rates. Regional patterns of asset values in relation to changes in the repo rate are evident from recent developments in the housing market. Higher UK interest rates have been designed partly to choke off a housing boom which was well-advanced in the South-East. But it also hit regional housing markets which are further behind in the house price cycle, ensuring that regional house price differentials are higher than would otherwise be the case, and limiting the value of the asset base. Figure 5 shows the annual house price inflation for Scotland, Greater London and the UK, while Figure 6 plots the houseprice differential between UK house prices and their value in Scotland and the Greater 
London region, respectively. From these two graphs it is clear that Scottish house prices fall behind Greater London increasingly as the housing boom there builds up, and continue to show a large absolute differential even after relative house prices in Greater London have peaked. This is an extreme example of the effect of monetary policy on regional prices. It is important because of different regional exposure to changes in borrowing costs, due to regional differences in indebtedness. The importance of mortgage indebtedness for disposable income and thus for consumption may well go a long way towards explaining the apparently greater impact of monetary policy on London and the South-East.

But the housing market experience illustrates what may be seen as a more general phenomenon, which is that monetary policy is tightened to dampen activity in the South-East (fuelled by the greater indebtedness itself). A rise in interest rates dampens activity in the South-East; where the level of indebtedness is high, the impact on disposable income of a rise in interest payments will be marked, showing up in the empirical analysis we have cited as a strong impact of monetary policy there. The impact of an interest rate rise will be less marked on activity elsewhere, because any boom is less well-advanced, and so the exposure to interest payments less. Nevertheless, the rise in interest rates will inhibit rising asset prices outside the SouthEast. The absence of a sharp reversal is the result of the absence of such a strong boom in the first place. There will be long experience in peripheral regions of periodic rises in interest rates, addressed to booms elsewhere, having the effect of choking off the potential for a boom. This encourages a generally more cautious attitude to expansion in peripheral regions, and therefore prevents the higher growth rates which might reduce regional disparities. These would be reflected in lower demand for 
credit in peripheral regions, and a higher risk premium on loans there, as we modelled for Region B in the previous section.

The appearance is of a greater impact of monetary policy where the housing boom or indeed the economic boom more generally - has been greatest, but in fact the more lasting dampening impact is on regions which have not experienced boom conditions. This will not show up in the reduced form analysis since it does not reveal how far planned expenditure is held back by long experience of expansions prematurely choked off by monetary policy. ${ }^{8}$ Thus, while the studies we have considered suggest greater impact of monetary policy in the South-East, the analysis only captures shortrun effects, while masking the long-run effects on behaviour. It is therefore necessary to consider financial behaviour in different regions more carefully in order to understand more fully the effects of national monetary policy.

A study was conducted some time ago comparing financial behaviour in Scotland with the rest of the UK (DOW, 1992). What was gleaned from the data which were available then was that there was indeed evidence of more conservative financial behaviour in Scotland, on the part of households, companies and banks, which on the one hand reduced volatility but on the other also reduced growth. The company sector is critical for regional outcomes; more investment in peripheral regions is critical for reducing regional disparities.

One source used in that study which we update here is the evidence provided by the Confederation of British Industry (CBI) Industrial Trends Survey. We have emphasised in the analysis above the importance of perceptions on the part of banks 
of default risk, and on the part of borrowers of financial vulnerability. The CBI survey provides good evidence on a regional basis of factors which enter into firms' output and investment plans. Where this evidence refers to financial conditions, we see the interdependence between firms' demand for credit and their expectation of how the banks would respond to credit requests.

Thus respondents are asked to say how far inability to raise external finance is expected to inhibit investment plans over the next year. The percentage to give a positive response is shown for Scotland and the UK in Figure 7, in relation to a common UK short-term interest rate, quarterly over the period 1993Q1 to 2002Q1. These relations can therefore be understood as the obverse of the perceived credit supply curve. This evidence therefore suggests a positively-sloped perceived supply curve for the UK, but a negatively-sloped perceived credit supply curve for Scotland. As monetary policy tightens, Scottish companies expect to find it more difficult to borrow.

Figure 8 shows the responses for cost of credit as an inhibitor of investment, again compared to a UK short-term interest rate. Even though we might expect borrowing costs to increase by more in Scotland for a given rise in the repo rate, the cost of finance is shown to be less of an inhibitor in Scotland than the UK as a whole. This implies a less elastic credit demand curve in Scotland.

It should be noted, however, that other variables are shown to have a more powerful inhibiting effect on investment, notably demand variables. Demand uncertainty in particular is noted as an inhibitor in around half of responses. There does not however 
appear to be any relationship between demand uncertainty and inability to raise external finance; the latter seems to have a closer relationship with monetary policy.

\section{Conclusion}

We have attempted here to consider how British monetary policy affects different regions, focusing on Scotland (for which there are relatively good data). It would appear on balance from the macro-level data that the greatest impact of monetary policy is on the South-East of England because of the pivotal role of housing finance. But by considering structural differences between regions, in terms of economic activity, financial behaviour and the transmission of monetary policy, we identified forces which would suggest the opposite to be the more general case. A resolution was suggested in thinking of monetary policy being driven by cyclical conditions in the South-East, where it therefore has the greatest immediate impact. But, since the cycle lags the South-East elsewhere, the outcome is a choking-off of growth in peripheral regions with the result that monetary policy has a more sustained impact there.

We have therefore attempted to extend the analysis of the regional impact of monetary policy in the UK. Reflecting developments in the monetary policy literature, we have explored a range of transmission mechanisms by which monetary policy impacts on regional economies. To pursue this further will require analysis of both the economic and financial structures of UK regions, and also of financial behaviour. This is very demanding of data, which are currently very limited. But we have attempted here to suggest some proxies where actual data do not exist, for the purpose of suggesting the direction for future research. 
There remains the question of what, if any, policy responses are available. A regional monetary policy was possible up to the 1960s, when credit controls were still an option and there was a more clearly regionally-distinct banking system in the UK. But financial innovation and the UK-wide banking sector now rule such a move out. Alternatives lie in the design of the financial structure on the one hand, and regional policy more generally on the other. A major source of financial constraints for peripheral regions was identified as poor knowledge of local borrowers. The public sector could intervene either by improving the knowledge base for private sector financial institutions, or by encouraging the kind of local mutual institutions (like credit unions) whose knowledge is already good. At the same time, regional policy can be designed to promote confidence in regional economies, not just in terms of productivity (as at present) but also in terms of promoting the mutual build-up of demand surrounding increased economic activity. The issue is one of encouraging confident long-term expectations in peripheral regions which are not knocked back by monetary policy suited to more expansive regional economies. 


\section{References}

ALLSOPP, C (2003) Review of Statistics for Economic Policymaking. London: Stationary Office for HMT.

ALLSOPP, C (2004) Review of Statistics for Economic Policymaking: Final Report. London: Stationary Office for HMT.

ARCHIBALD, G C (1969) 'The Phillips curve and the distribution of unemployment', American Economic Review Papers and Proceedings, 59, 124-129.

BANK OF ENGLAND (1999) 'The Transmission of Monetary Policy’, Bank of England Quarterly Bulletin, May.

BELL, D N F (1993) 'Regional Econometric Modelling in the UK: A Review', Regional Studies 27 (8), 777-82.

BERNANKE, B. and GERTLER, M. (1995) 'Inside the Black Box: The Credit Channel of Monetary Policy Transmission' The J ournal of Economic Perspectives, 9 (4), 27-48.

BLAKE, N (1995) 'The Regional Implications of Macroeconomic Policy', Oxford Review of Economic Policy 11 (2), 145-65.

CBI (Various years) ‘CBI Industrial Trend Survey’, London, UK.

CHICK, V and DOW, S C (1988) 'A Post Keynesian Perspective on Banking and Regional Development', in P Arestis (ed), Post Keynesian Monetary Economics, Edward Elgar: 219-250.

CLARIDA, R., GALI, J. AND GERTLER, M (1999) 'The Science of Monetary Policy - A New Keynesian Perspective', Journal of Economic Literature, 37 (4), pp. 1661-1707.

DE BONDT, G J (2000) Financial Structure and Monetary Transmission in Europe: A CrossCountry Study. Cheltenham: Edward Elgar.

DOW, J C R and SAVILLE, I (1990) A Critique of Monetary Policy. Oxford: Oxford University Press.

DOW, S C (1992) 'The Regional Financial Sector: A Scottish Case Study’, Regional Studies, 26 (7), 619-31. 
DOW, S C (1998) 'Knowledge, Information and Credit Creation', in Rotheim, R (ed), New Keynesian Economics, Routledge: 214-26.

DOW, S C (2006) ‘Endogenous Money: Structuralist’, P Arestis and M Sawyer (eds), A Handbook of Alternative Monetary Economics. Cheltenham: Edward Elgar

EVANS, P and McCORMICK, B (1994) 'The New Pattern of Regional Unemployment: Causes and Policy Significance’, Economic Journal 104 (424), 63347.

FISHKIND, H H (1977) 'The Regional Impact of Monetary Policy: An Econometric Simulation Study of Indiana 1958-73', Journal of Regional Science 17 (April).

FRIEDMAN, B M (1999) 'The Future of Monetary Policy: The Central Bank as an Army with only a Signal Corps?', International Finance 2 (3), 321-38.

GANLEY, J AND SALMON, C (1997) 'The Industrial Impact of Monetary Policy Shocks: Some Stylised Facts’, Bank of England Working Paper 68.

HMT (2001) Productivity in the UK 3: The Regional Dimension. London: Stationary Office.

KASHYAP, A K and STEIN, J (2000) 'What do a million observations on banks say about the transmission of monetary policy?', American Economic Review 90 (3), 40728.

LEVIN, E J, MONTAGNOLI, A and WRIGHT, R E (2004), “Demographic Change and the Scottish Housing Market”, Scottish Economic Policy Network, in press.

McKILLOP, D G and HUTCHINSON, R W (1990) Regional Financial Sectors in the British Isles. Aldershot: Gower.

MILLER, R J (1977) The Regional Impact of Monetary Policy in the United States. Lexington, MA: D C Heath \& Co. PORTEOUS, D J (1995) The Geography of Finance. Aldershot: Gower. 
REDWOOD, V and TUDELA, M (2004) 'From tiny samples do mighty populations grow? Using the British Household Panel Survey to analyse the household sector balance sheet', Bank of England Working Paper no. 239, October.

RODRIGUES FUENTES, C (2005) Regional Monetary Policy. London: Routledge.

RODRIGUES FUENTES, C and DOW, S C (2003) 'EMU and the Regional Impact of Monetary Policy’, Regional Studies 37 (9), 973-84.

WALSH, C (2003) Monetary Theory and Policy. Cambridge, MA: MIT Press 
Figure 1. The regional credit market under discriminating monopoly: transmission through the marginal cost of funds to the banks

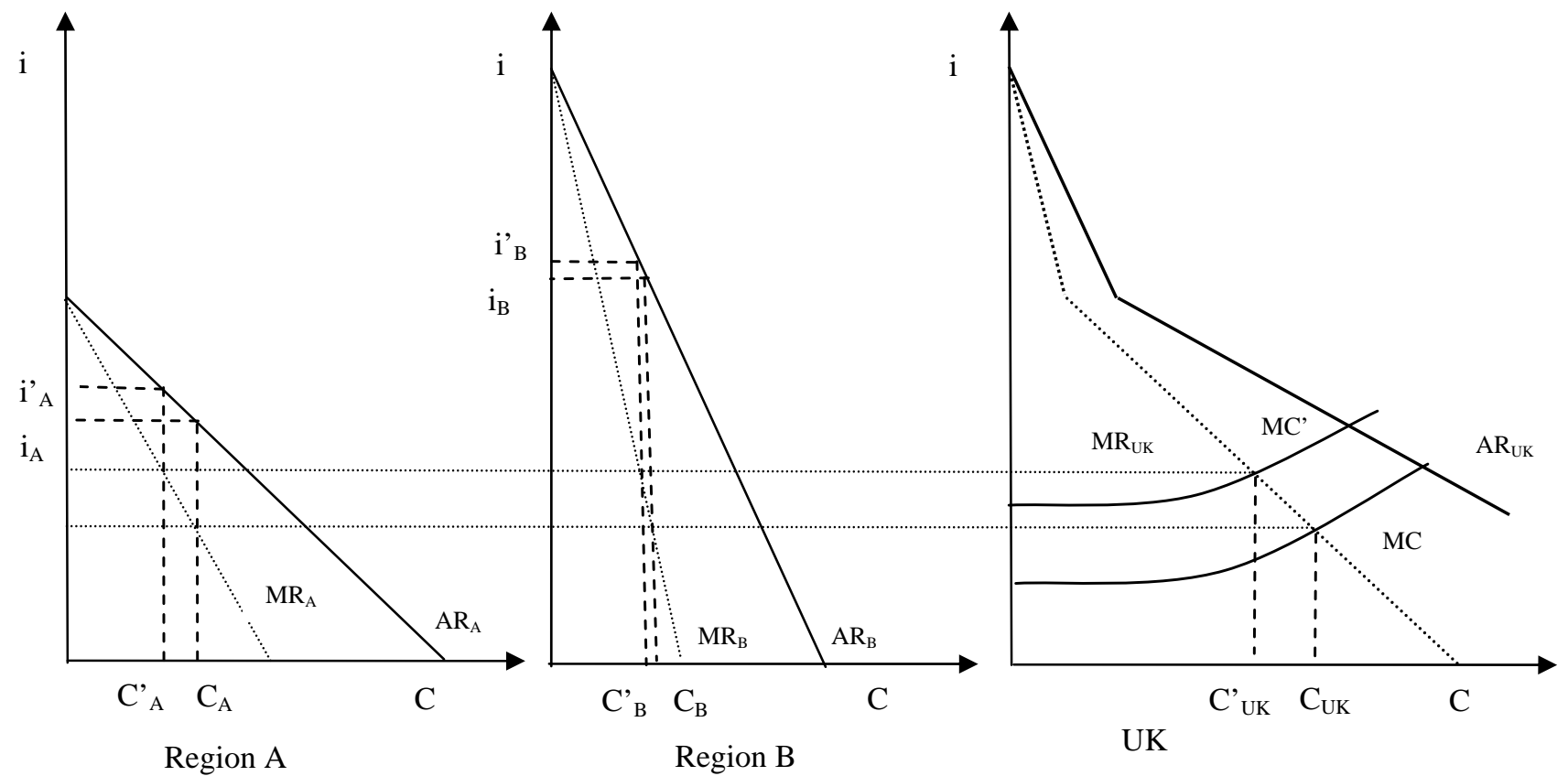


Figure 2: The regional credit market under discriminating monopoly: transmission through lender's risk

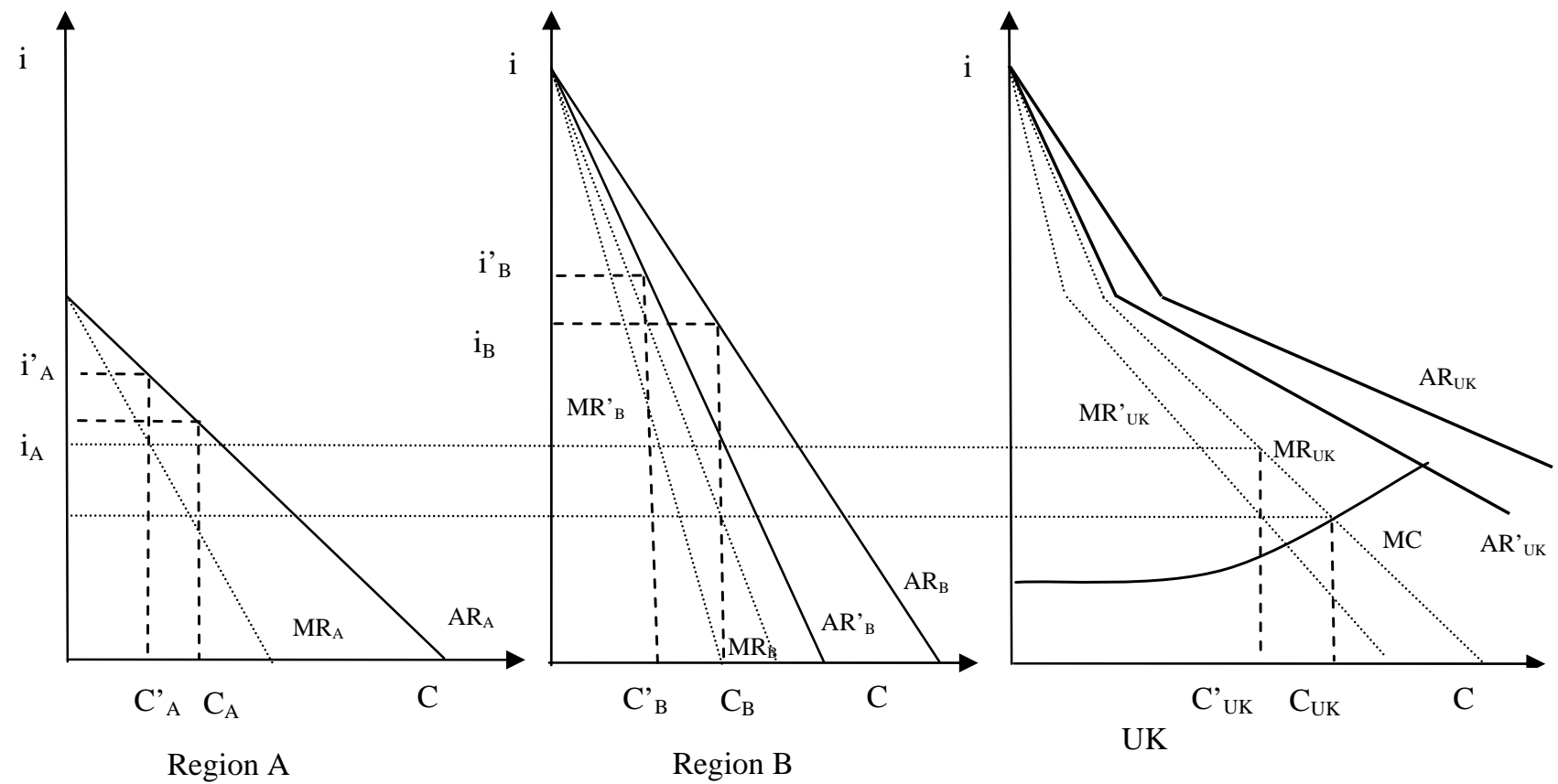


Figure 3. The regional credit market under discriminating monopoly: transmission through the demand for credit

0

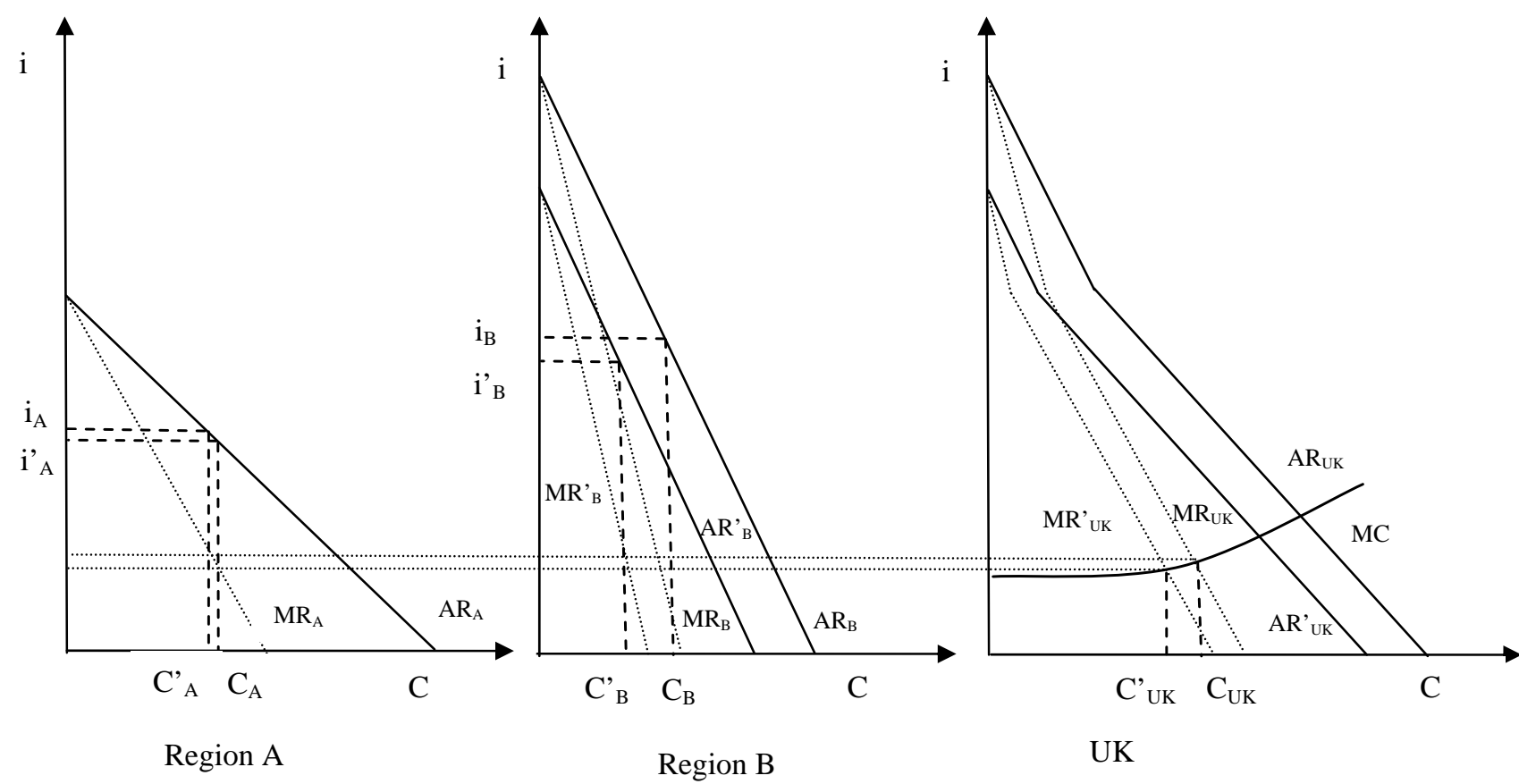


Figure 4: Phillips curves: South-East, Wales, Scotland, England and GB, 1994-2001
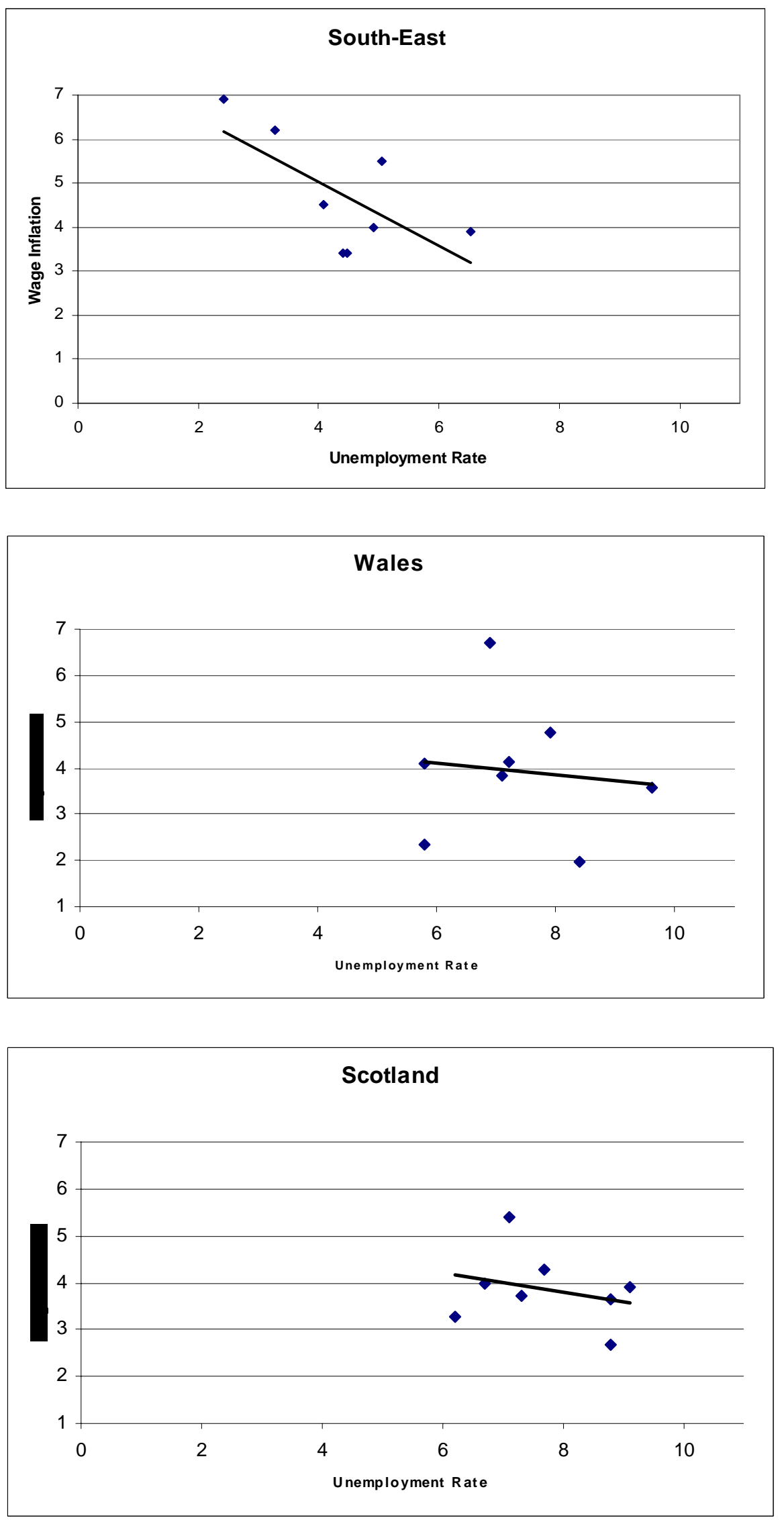

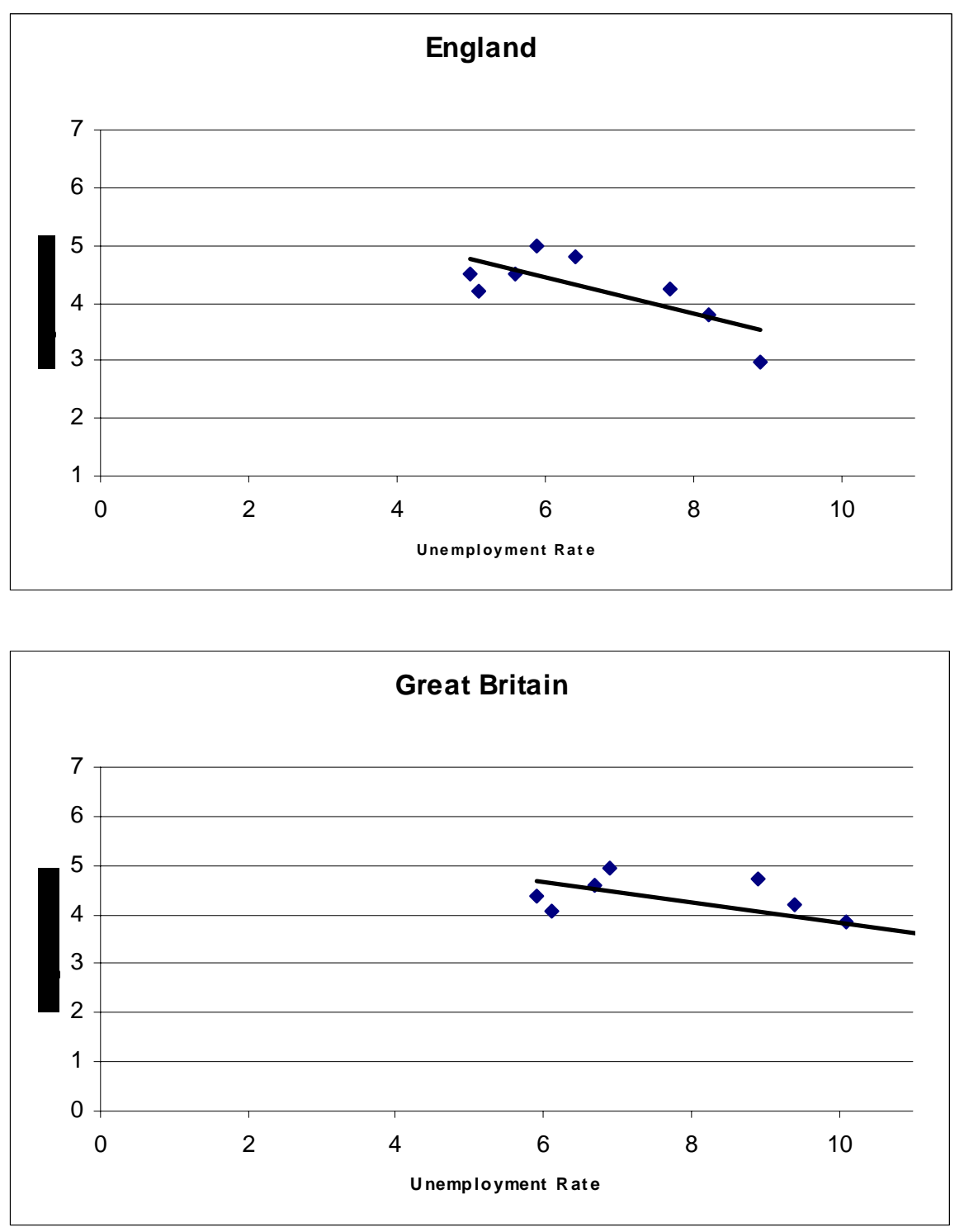
Figure 5: Annual house price inflation, Scotland, Greater London and the UK, 1984Q1-2005Q4

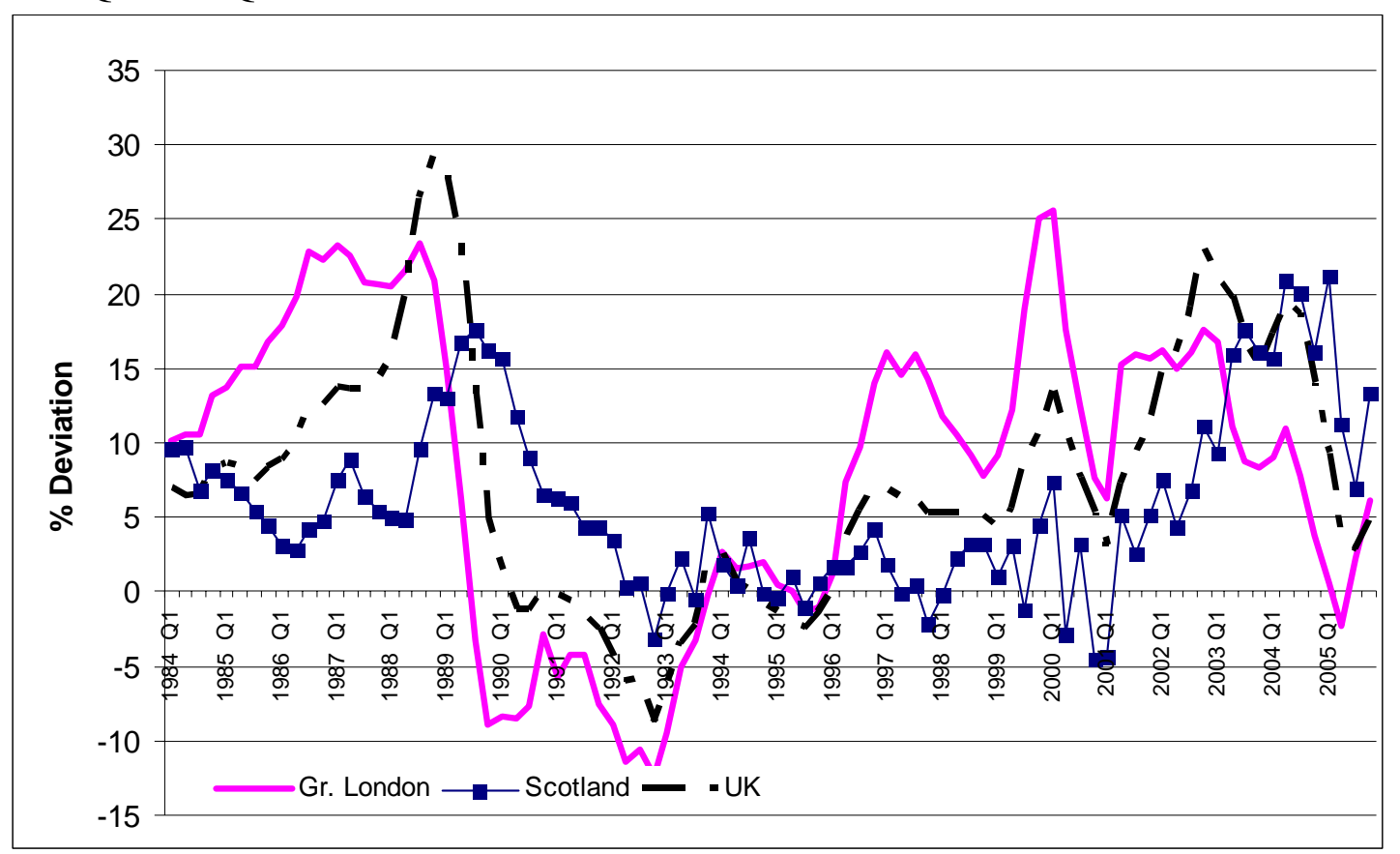

Source: Halifax Bank of Scotland Database. 
Figure 6: Percentage deviations of Scottish and Greater London house price indices from UK average, 1983Q1-2005Q4 ${ }^{1}$

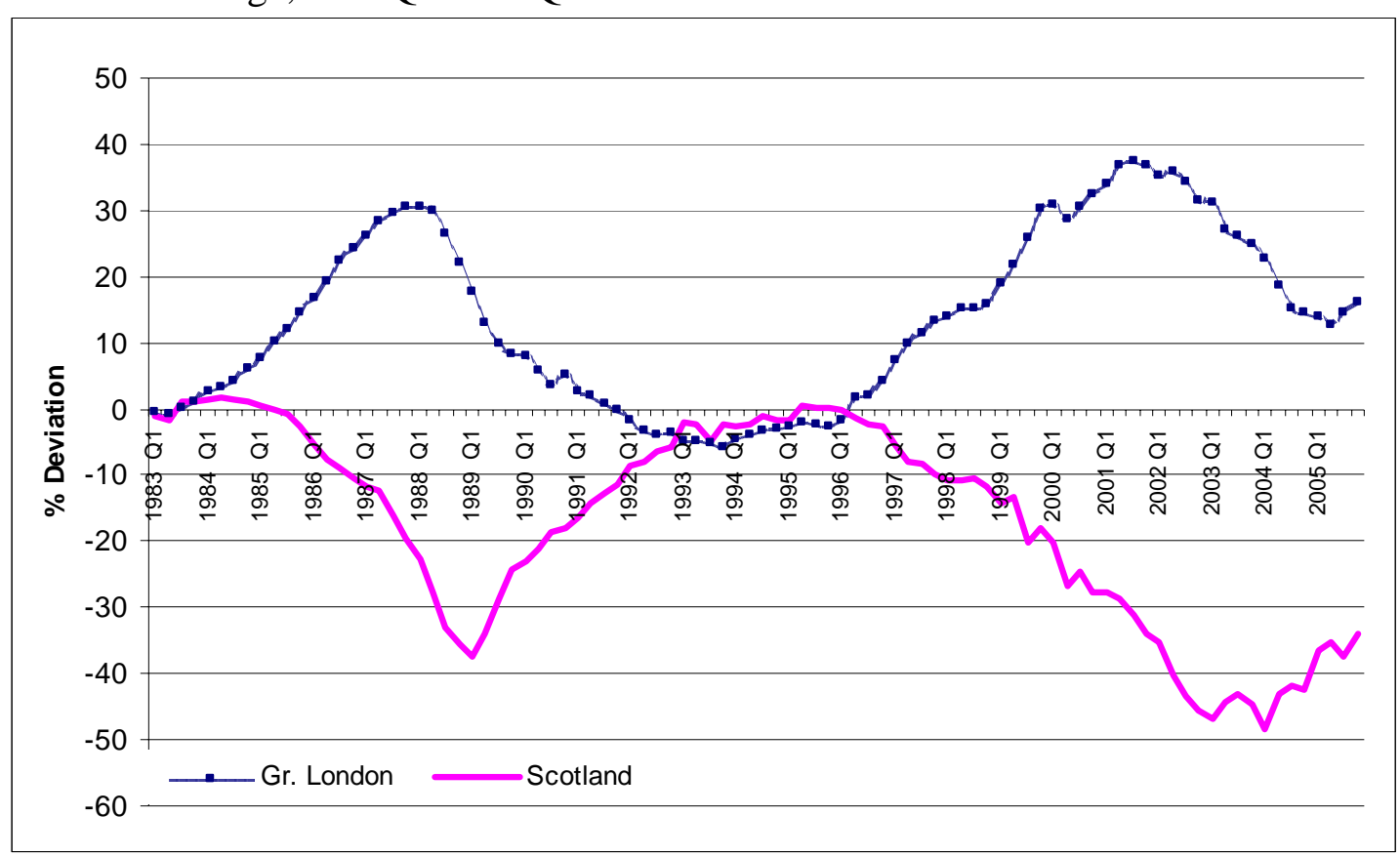

${ }^{1}$ The deviation is calculated as $100 * \ln$ (Region Price/UK Price)

Source: Halifax and Bank of Scotland database 
Figure 7: Relation between short term interest rate and inability to raise external finance, as factor limiting production (1993QI-2002QI)
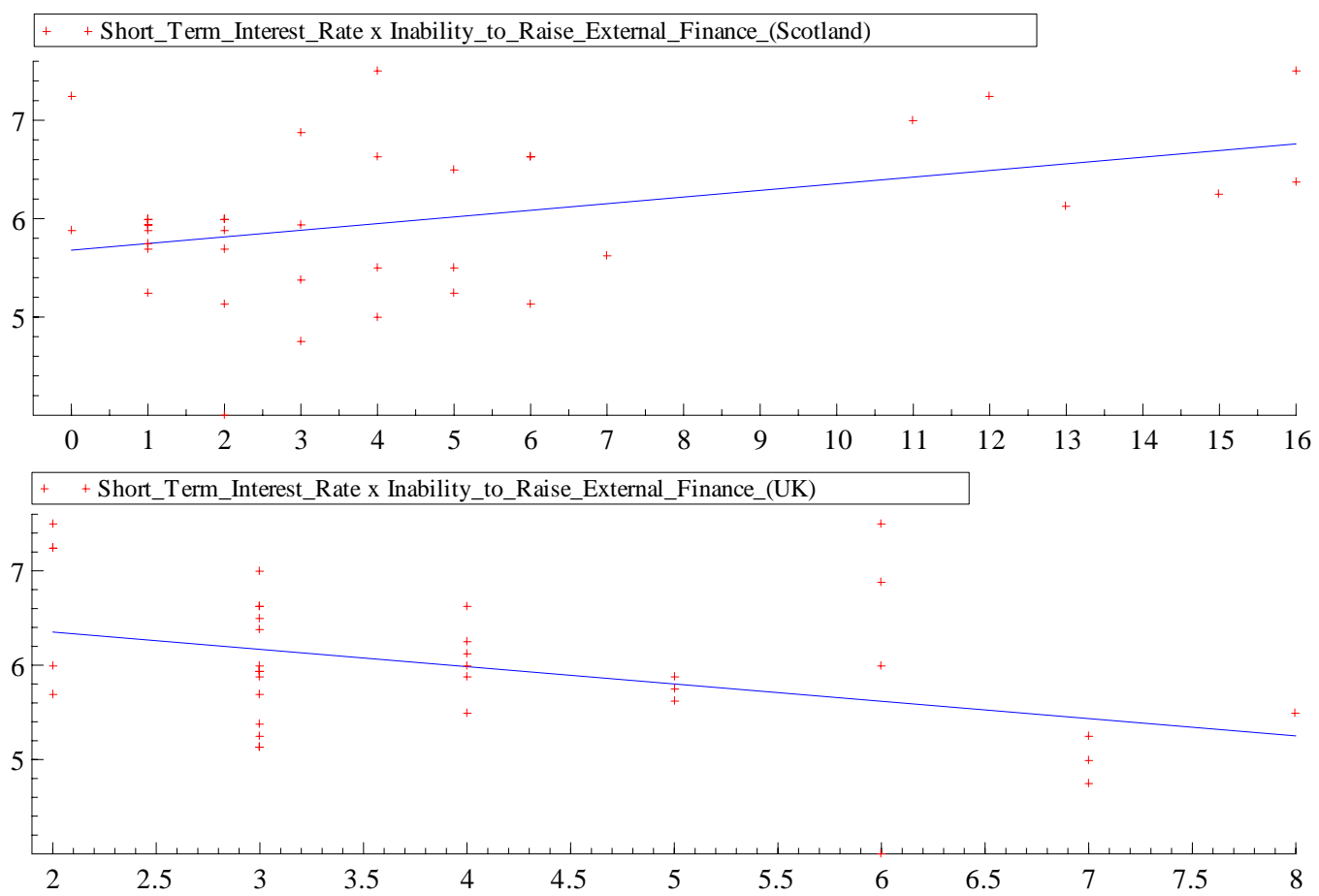

Sources : Short-term interest rate data are from the Bank of England website, inability to raise external finance data are from the CBI Industrial Trends Survey. 
Figure 8: Relation between short term interest rate and cost of finance as factor limiting production (1993QI-2002QI)
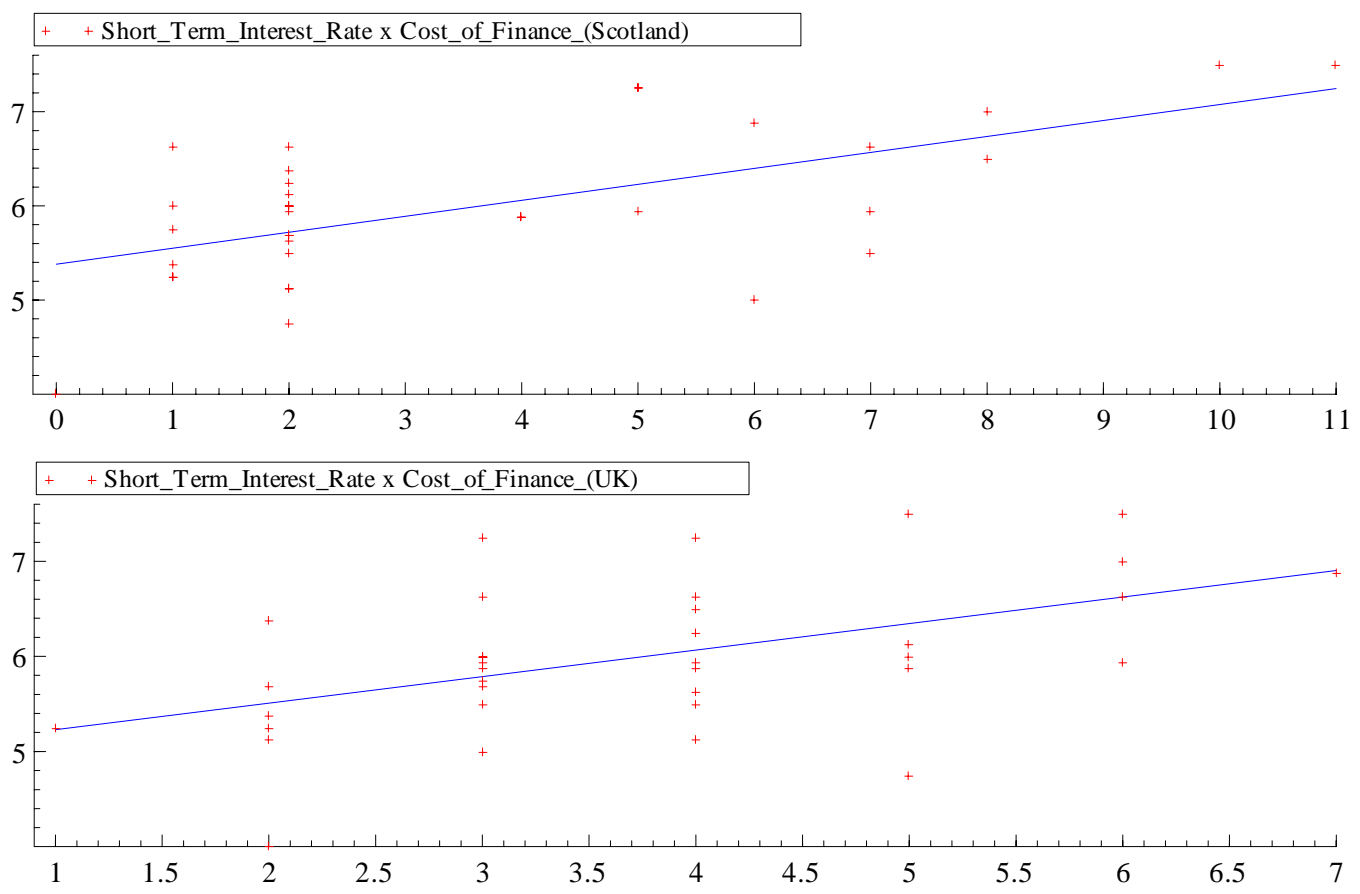

Sources: Short-term interest rate data are from the Bank of England website, cost of finance data are from the CBI Industrial Trends Survey. 
${ }^{1}$ We would like to thank David Bell, Elizabeth Roberts Carlos Rodriguez Fuentes and the participants at the 2004 Regional Studies Working Group/URESG Financing Regional Economies seminar at the Centre for Urban and Regional Development Studies (CURDS), University of Newcastle Upon Tyne, for their valuable comments and suggestions on an earlier version of this paper. Any remaining errors are the sole responsibility of the authors.

${ }^{2}$ See among others BERNANKE and GERTLER (1995) and CLARIDA ET AL. (1999).

${ }^{3}$ The repo rate is the rate implied by the terms for sale and repurchase agreements, usually for two weeks, and usually for government bonds. In the text repo rate and risk-free interest rate are used interchangeably.

${ }^{4}$ This represents a change from a $2.5 \%$ target in terms of RPIX announced in November 2003.

CPI and RPIX refer to the consumer price index, and retail price index excluding mortgage interest payments, respectively.

${ }^{5}$ See WALSH (2003) for a comprehensive survey of the literature.

${ }^{6}$ A more regionally-structured banking system than prevails in the UK would be better analysed in terms of distinct regional supply curves.

${ }^{7}$ We have here a simple version of the lending channel; a more complete analysis would take account of a more complex regional financial structure.

${ }^{8}$ See LEVIN, MONTAGNOLI and WRIGHT (2004) for an analysis of the impact of monetary policy and other factors on the regional housing market. 
